BOGDAN KULIK

Uniwersytet im. Adama Mickiewicza w Poznaniu

Wydział Teologiczny

\title{
De arte moriendi Jana Gersona - średniowieczny przeżytek czy dar dla współczesnych? Próba analizy w świetle dokumentu Aktualne problemy eschatologii Międzynarodowej Komisji Teologicznej (1992)
}

Śmierć zawsze skłaniała człowieka do stawiania pytań: o jej pochodzenie, o jej sens i o to, co po niej nastąpi. Do tych pytań ludzie wszystkich czasów dołączali jeszcze jedno: Jak się do śmierci przygotować? Odpowiedzi były różne. Zależały od tego, kto pytał i w jakich czasach żył. Wbrew obiegowym opiniom problem ten zaprzątał nie tylko umysły ludzi średniowiecza ${ }^{1}$. Dzieła z gatunku ars moriendi powstawały także w kolejnych wiekach ${ }^{2}$.

\footnotetext{
${ }^{1} \mathrm{Na}$ temat średniowiecznej literatury ars moriendi zob. np. K. Bartoszewski, J. Zbiciak, Ars moriendi, w: Encyklopedia katolicka, red. F. Gryglewicz i in., Lublin 1973, t. 1. kol. 950-951; K. Baumgartner i in., Ars moriendi, w: Lexikon für Theologie und Kirche, red. W. Kasper i in., Freiburg-Basel-Rom-Wien 1993³, t. 1, kol. 1035-1038; M. Włodarski, Ars moriendi w literaturze polskiej XV i XVI w., Kraków 1987; tenże, Trzy traktaty o sztuce umierania, Kraków 2015; H. Rolfes, Ars moriendi. Eine Sterbekunst aus der Sorge um das ewige Heil, w: Ars moriendi. Erwägungen zur Kunst des Sterbens, red. H. Wagner, T. Kruse, Quaestiones Disputatae 118, Freiburg-Basel-Wien, 1989, s. 25-36; J. Misiurek, „Ars moriendi” - sztuka umierania, w: Cierpienie i śmierć, red. A. Nowak, Homo Meditans 13, Lublin 1992, s. 231-244; M. Machinek, Czy umieranie jest sztuką? O chrześcijańskiej ,ars moriendi”, w: Śmierć $i$ wiara $w$ życie pośmiertne $w$ świetle nauk przyrodniczych $i$ humanistycznych, red. tenże, Biblioteka Wydziału Teologii 17, Olsztyn 2003, s. 245-248; tenże, Towarzyszyć w ostatniej drodze. „Metoda asystowania umierajacym” ks. Jana Berthiera a wspótczesna troska o umierajacych, w: Cor unum et anima una, red. A.J. Sobczyk, Pelplin 2009, s. 82-86.

${ }^{2}$ Np. R. Bellarmin, De arte bene moriendi (1620), tekst angielski zob. https://archive.org/ details/theartofdyingwel00belluoft [dostęp: 03.04.2017], A. Liguori, Przygotowanie do śmierci (1758), Kraków 2016, J. Berthier, Metoda asystowania umierającym (1891), Górka Klasztorna 2015; zob. także: W. Biedrzycki, Przy łożu śmierci. „Metoda towarzyszenia umierającym” ks. Jana
} 
Także dzisiaj pojawiają się książki, które bezpośrednio nawiązują do traktatów o sztuce umierania lub próbują odpowiedzieć na to samo pytanie: Jak przygotować się do śmierci? ${ }^{3}$ Co więcej, także wśród teologów słychać głosy, które mobilizują do pochylenia się nad tym chyba najbardziej życiowym tematem, do przemyślenia go na nowo, oczyszczenia z nieprzydatnych naleciałości historycznych i do podania go dzisiejszemu człowiekowi w „strawnej” formie jako antidotum na bezbożny lęk przed umieraniem lub na bagatelizowanie śmierci ${ }^{4}$.

Wydaje się, że pierwszym krokiem, jaki powinien uczynić teolog podejmujący próbę opracowania „nowej ars moriendi dzisiaj”, jest zbadanie, czy przekazywane w klasycznych traktatach prawdy dotyczące rzeczy ostatecznych człowieka są zgodne ze współczesną nauką Kościoła na ten temat. Tylko poprawna eschatologia może stać się bazą opracowania współczesnej sztuki dobrego umierania. Wychodząc z takiego założenia, jako cel niniejszego artykułu przyjęto próbę analizy teologii rzeczy ostatecznych człowieka zawartej we wzorcowym ${ }^{6}$ traktacie gatunku ars moriendi, autorstwa kanclerza uniwersytetu paryskiego, średniowiecznego teologa Jana Charliera (1363-1429), znanego tak-

B. Berthiera, w: Śmierć $i$ wiara, dz. cyt., 257-267; Na temat rozwoju „sztuki dobrego umierania” zob. M. Włodarski, Trzy traktaty, dz. cyt., s. 33-37.

${ }^{3}$ Np. Ars moriendi ars vivendi ars educandi, red. Z. Rudnicki, Poznań 2012; B. PieńkowskaWyżyńska, Sztuka dobrego umierania, Kraków 2015; L. Bartoszewski, Zanim nadejdzie śmierć... czyli ars bene moriendi, Gdańsk 2015, A. Zwoliński, Ars moriendi. Sztuka towarzyszenia umierajacym, Poznań 2016.

4 „Jest rzeczą oczywistą, iż współczesność nie może bezpośrednio sięgnąć po późnośredniowieczne traktaty, które przecież wyrosły na bazie ówczesnej umysłowości i mentalności, a także wyzwań tamtych czasów. [...] Mimo tych zasadniczych różnic wydaje się iż [...] klasyczna ars moriendi może zainspirować również ludzi współczesnych" - M. Machinek, Czy umieranie jest sztuka?, dz. cyt., s. 249; zob. także: tenże, Śmierć w dyspozycji człowieka. Wybrane problemy etyczne u kresu ludzkiego życia, Biblioteka Wydziału Teologii 22, Olsztyn 2004², s. 170; J. Wohlmuth, Mistro della trasformazione. Tentativo di una escatologia tridimensionale, in dialogo con il pensiero ebraico e la filosofia contemporanea, Biblioteca di teologia contemporanea 164, Brescia 2013, s. 213; H. Rolfes, Ars moriendi, dz. cyt., s. 36-44; J. Manser, „,Wer mich zum Freunde hat, dem kann's nicht fehlen". Versuch einer spirituellen Theologie zur Ars moriendi heute, w: Ars moriendi, red. H. Wagner, T. Kruse, dz. cyt., s. 69-98; H. Wagner, ,Ars moriendi” und Religionspädagogik, w: Ars moriendi, red. H. Wagner, T. Kruse, dz. cyt., s. 156-165.

5 Taki tytuł nosi jeden z paragrafów tekstu M. Machinka pt. Czy umieranie jest sztuka?, dz. cyt., s. 249 .

6 Tekst ten uznawany jest za jeden z tzw. traktatów „,wzorcowych”, znajdujących się u podstaw szczególnego gatunku piśmiennictwa chrześcijańskiego zwanego „traktatami de arte bene moriendi” czyli „sztukami dobrego umierania”, których przykłady znajdujemy także w późniejszych epokach, właściwie aż do wieku XX. Były one jak gdyby „podręcznikami, podającymi sposób najbardziej bezpiecznego, prowadzącego do zbawienia, a zatem dobrego umierania”, zob. M. Włodarski, Trzy traktaty, dz. cyt., s. 16, 33, 37. De arte moriendi Gersona stał się wzorcem do powstania innych dzieł zmagających się z udzieleniem praktycznych odpowiedzi na pytanie o najlepsze przygotowanie się na śmierć. Przede wszystkim chodzi tu o dwa dzieła: Traktat Ars moriendi ex variis scripturarum sententiis collecta nieznanego autora, jednak przypisywany Mateuszowi z Krakowa (ok. 1345-1410) - teologowi, filozofowi, rektorowi uniwersytetu w Heidelbergu, profesorowi Akademii 
że jako Jan Gerson ${ }^{7}$. W swoim dziele napisanym po łacinie ok. 1408 roku pt. Podzielone na trzy części dzietko o przykazaniach Dekalogu, o spowiedzi i o sztuce umierania (Opusculum tripartitum de praeceptis decalogi, de confessione et de arte moriendi) trzecią część, zatytułowaną: „O sztuce umierania” (De arte moriendi $)^{8}$, poświęca tematowi przygotowania się do dobrego umierania.

Właśnie ta część będzie przedmiotem niniejszego studium.

W pierwszym paragrafie zostanie ukazana nauka Gersona o rzeczach ostatecznych człowieka. Celem paragrafu drugiego będzie nakreślenie współczesnej eschatologii na podstawie dokumentu Międzynarodowej Komisji Teologicznej pt. Aktualne problemy eschatologii (1992) $)^{9}$. Dokument wydaje się właściwym punktem odniesienia w przypadku podjęcia próby zbadania aktualności eschatologii zawartej w De arte moriendi Gersona, gdyż, jak stwierdził kard. Ratzinger, jego zamierzeniem jest ,właśnie podjąć na nowo punkty fundamentalne zagadnień związanych z nadzieją eschatologiczną, przedstawiając refleksję organiczną i opracowaną w sposób spekulatywny, jednocześnie starając się usilnie udzielić chrześcijańskiej odpowiedzi na wątpliwości i oczekiwania człowieka współczesnego, jak i człowieka każdego czasu"10.

Trzeci paragraf będzie próbą wskazania zbieżności i ewentualnych różnic w nauczaniu zawartym w De arte moriendi i w dokumencie Aktualne problemy eschatologii. To porównanie pozwoli ostatecznie potwierdzić lub odrzucić postawioną tezę o ponadczasowej wartości średniowiecznego traktatu.

Krakowskiej, i traktat Speculum artis bene moriendi przypisywany kard. Dominikowi Capranice (1400-1458), biskupowi Fermo; zob. tamże, s. 19, 26.

${ }^{7} \mathrm{Na}$ temat Gersona zob. np. S. Wielgus, Gerson, w: Encyklopedia katolicka, red. L. Bienkowski i. in, Lublin 1989, t. 5, kol. 1018-1020; K. Hausberger, Johannes Chalier Gerson, w: Leksikon für Theologie und Kirche, red. W. Kasper i. in., Freiburg-Basel-Rom-Wien 1996³ , t. 5, kol. 909-910; M. Włodarski, Trzy traktaty, dz. cyt., s. 17-19.

8 J. Gerson, De arte moriendi, przekład i opracowanie M. Włodarski, w: M. Włodarski, Trzy traktaty, dz. cyt., s. 43-62.

9 Międzynarodowa Komisja Teologiczna, Aktualne problemy eschatologii (1992), http:// www.vatican.va/roman_curia/congregations/cfaith/cti_documents/rc_cti_1990_problemi-attualiescatologia_pl.html [dostęp: 03.04.2017].

10 J. Ratzinger, Introduzione, w: Congregazione per la Dottrina della Fede, Temi attuali di escatologia, Vaticano 2000, s. 15. Dokument Międzynarodowej Komisji Teologicznej (dalej jako MKT) wielokrotnie przywołuje inne dokumenty zawierające oficjalną doktrynę Nauczycielskiego Urzędu Kościoła, szeroko je komentując i wyjaśniając w świetle współczesnych wątpliwości dotyczących śmierci i życia wiecznego. Przede wszystkim chodzi o Konstytucję dogmatyczną o Kościele Lumen Gentium nr 48-51; Konstytucję duszpasterską o Kościele Gaudium et spes 38-39; Wyznanie wiary Pawła VI (1968); List Kongregacji Nauki Wiary Recentiores episcoporum Synodi (1979); tekst polski: BF 1471-1480. Dokument nie odwołuje się do Katechizmu Kościoła katolickiego, najprawdopodobniej dlatego, że został on zatwierdzony przez Jana Pawła II w czerwcu i opublikowany w październiku 1992, czyli krótko przed ogłoszeniem dokumentu Międzynarodowej Komisji Teologicznej, które miało miejsce w grudniu tego samego roku; zob. J. Ratzinger, Introduzione, dz. cyt., s. 15. 


\section{Rzeczy ostateczne w De arte moriendi Jana Gersona}

De arte moriendi zawiera cztery punkty: (1) napomnienia (exhortationes); (2) pytania do umierającego (interrogationes); (3) modlitwy (orationes); (4) przepisy (observationes). Gerson już na wstępie określa cel swojego dziełka, wyjaśniając, że ,podjęte zostało zadanie ułożenia w niniejszym piśmie pewnego krótkiego sposobu napominania, jakie należy czynić wobec tych, którzy zostali postawieni w obliczu śmierci, przydatnego także ogólnie dla wszystkich katolików, aby została stworzona sztuka i wiedza o dobrym umieraniu" ". Nie dziwi zatem, że najczęściej wspominaną rzeczą ostateczną człowieka jest jego śmierć. Autor mówi o niej wprost w różnych kontekstach 11 razy (6 razy posługując się terminem ,śmierć”, a 5 terminem „umieranie”) i dwa w sposób metaforyczny (nazywając śmierć „odchodzeniem z tego świata" i „karą miecza").

Ponieważ traktat skierowany jest przede wszystkim do osób złożonych chorobą, zatem śmierć jest w nim przedstawiona jako konsekwencja choroby. Gerson nie zajmuje się śmiercią z innych powodów. W pierwszym napomnieniu autor przypomina powszechność śmierci, której nikt - „królowie, książęta, bogaci i biedni" - nie może uniknąć, ponieważ taka jest wola Boga. Jest ona zatem czymś nieuniknionym dla osób wszelkiego stanu i pozycji społecznej „wszyscy [...] musimy zapłacić daninę śmierci”" ${ }^{2}$. Dalej autor uświadamia, że śmierć może być „nagłą”. Wydaje się, że taką śmierć uznaje za coś niepożądanego, ponieważ nakazuje choremu, aby za jedno z Bożych dobrodziejstw uznał z wdzięcznością ,także to, że dał [...] [mu] w tej ostatniej godzinie świadomość i że nie zaskoczył [...][go] nagłą śmiercią"13.

Dalej Gerson ukazuje śmierć jako karę za grzechy, którą trzeba znosić dobrowolnie i z cierpliwością, aby dostąpić darowania wszelkich grzechów, win i kar $^{14}$. Jednocześnie w tej „ostatniej godzinie” moribond powinien zająć się „rozważaniem”, „rozmyślaniem”, „porzuceniem wszelkich innych trosk i zabiegów o sprawy ziemskie”. Jest to bowiem moment „poruczenia się Bogu” $\mathrm{z}$ wiarą ${ }^{15}$.

Chwila śmierci jest także pokazana jako wydarzenie, które daje możliwość podjęcia ostatniej, osobistej i wolnej decyzji. Świadczy o tym nakaz stawiania pytań choremu, na które ma każdorazowo odpowiadać: „chcę”. Pytania dotyczą przede wszystkim jego chęci umierania w wierze chrześcijańskiej, w wier-

\footnotetext{
11 J. Gerson, De arte moriendi, w: M. Włodarski, Trzy traktaty, dz. cyt. s. 50.

12 Tamże, s. 53.

13 Tamże.

14 Tamże.

15 Tamże.
} 
ności i posłuszeństwu Bogu i świętej matce Kościołowi ${ }^{16}$. Poza tym ma zdecydować, czy będzie prosić Boga o odpuszczenie wszelkich zaniedbań. Ma także jasno określić, czy poprawiłby się w razie „,przedłużenia jego życia”, czy jest gotowy do zadośćuczynienia za wszystkie wyrządzone szkody, czy przebacza wszystkim i czy prosi ich o przebaczenie. „Na te wszystkie wcześniej wyrażone pytania niech odpowie potwierdzająco: [tak], chcę"17.

Umieranie jest także czasem intensywnej i żarliwej modlitwy błagalnej kierowanej do Boga zarówno przez samego chorego, jak i jego bliskich. Dlatego trzecia część dziełka jest zbiorem krótkich modlitw, przede wszystkim do Boga Ojca, Jezusa, Dziewicy Maryi-Królowej Niebios, Matki Miłosierdzia i Ucieczki Grzeszników. Gerson nawołuje także do wzywania wstawiennictwa aniołów, z Aniołem Stróżem na czele, a także świętych, których umierający w szczególny sposób czcił podczas swojego życia ${ }^{18}$. Ta prośba o wsparcie mieszkańców nieba jest bardzo istotna, gdyż śmierć to moment cierpienia, trwogi i ostatecznej potrzeby ${ }^{19}$. Tym samym jest momentem ostatniej szansy, którą dobrze należy wykorzystać. Z tego powodu Gerson oprócz wspomnianych modlitw podaje ,,pewne przepisy, aby było wiadomo, jak należy skorzystać z wcześniejszych zaleceń" ${ }^{20}$. Przypomina o zapewnieniu zbliżającemu się do kresu życia pobożnego przyjęcia sakramentów: spowiedzi, Eucharystii i ostatniego namaszczenia. Podkreśla także konieczność uwolnienia od ewentualnej ekskomuniki, jeśli takowa ciążyłaby na chorym. Ponieważ śmierć nie zawsze jest „szybka”, należy czas ją poprzedzający wykorzystać na pomoc w dokonaniu dobrego żalu za grzechy i przygotowanie swego sumienia. Należy w tym celu czytać pobożne historie, wyliczać przykazania Boże, ukazywać „wyobrażenia” krzyża lub świętych ${ }^{21}$.

Mimo że Gerson nie nazywa śmierci ani bra mą, ani przej ści e m do życia wiecznego, jednak jej ścisły związek z pozostałymi rzeczami ostatecznymi człowieka wynika z kontekstu. Śmierć jest łączona z „odchodzeniem z tego świata” do „chwały wiecznej”, wspólnoty duchów niebiańskich przy jednoczesnym uniknięciu „straszliwych kar piekielnych”. Natomiast sposób jej „znoszenia” wpływa na intensywność następującego po niej czyśćca ${ }^{22}$.

Stan wiecznego szczęścia po śmierci jest wspominany w traktacie siedem razy. Gerson najczęściej nazywa go: „rajem”23 (4 razy), „chwałą wieczną,"24,

16 Tamże.

17 Tamże, s. 56.

18 Tamże, s. 56, 59.

19 Tamże, s. 59.

20 Tamże.

21 Tamże.

22 Tamże, s. 53, 59.

23 Tamże.

24 Tamże, s. 53. 
„chwałą Jednorodzonego Syna Królowej niebios”25, „wspólnotą aniołów, duchów niebieskich"26.

Jeśli chodzi o raj, to interesujący jest fakt, że trzykrotnie zostaje wspomniany $w$ trzeciej cząstce traktatu, czyli w krótkich modlitwach, jakie chory winien zanosić do Boga przed śmiercią. Ma być upragniony przez umierającego, który o niego prosi, uznając, że nie jest on owocem jego zasług, lecz skutkiem „błogosławionej Męki”, zapłatą za „cenę krwi” Zbawiciela, przez które zechciał On go „odkupić” i „wykupić” dla raju, aby mu go „przybliżyć”27.

Gdy chodzi o chwałę wi ec zną, to zwrot ten został użyty w kontekście wyjaśniania powodu pojawienia się każdego człowieka na świecie. Według Gersona świat, czyli doczesność, nie jest celem samym w sobie, nie mamy na nim „zakładać siedziby”, ale poprzez dobre życie i służbę Bogu mamy osiągnąć właśnie chwałę wie c zną. Wynika z tego, że ona jest celem życia człowieka. Podobnie ma się rzecz z chwałą Jednorodzonego Syna Królowej niebios, do którego chory chce być przez Zbawiciela „zawiedziony”. Duchy niebiańskie, czyli aniołów, prosi natomiast o ,przyjęcie jego duszy do ich wspólnoty" ${ }^{28}$. Warto dodać, że Gerson trzy razy mówi także o „zbawieniu (duchowym)"29, które można by uznać za synonim wiecznego szczęścia.

Przeciwieństwem raju, chwały, wspólnoty aniołów i zbawienia jest inny stan, do którego człowiek może trafić po śmierci. Gerson wprost uczy o nim cztery razy, używając następujących określeń: „straszliwe kary piekielne”, „wieczna kara i potępienie”, „przepaść piekielna”" ${ }^{30}$, potępienie” ${ }^{31}$. Ponadto jeden raz robi do niego aluzję, mówiąc o niebezpieczeństwie, jakie czyha na duszę chorego, który musi się modlić, ,aby nie została pochwycona przez złe duchy i pożarta przez psy piekielne" ${ }^{32}$. Stan ten jest jednoznacznie uważany za negatywny, groźny, sprzeczny z celem życia człowieka. Dlatego trzeba tak żyć (dobrze, godnie, służąc Bogu, znosząc cierpliwie chorobę i śmierć, porzuciwszy „wszelkie inne troski i zabiegi o sprawy ziemskie”), aby go „uniknaćc"33. Nieodzowne jest do tego wsparcie Boga Ojca i Pana, o które chory ma się mo$\mathrm{dlic}^{34}$. Zabronione jest także dawanie umierającemu ,nadmiernej nadziei uzy-

\footnotetext{
25 Tamże, s. 56, 59.

26 Tamże, s. 59.

27 Tamże, s. 56.

28 Tamże, s. 59.

29 Tamże, s. 53, 59.

30 Tamże, s. 53.

31 Tamże, s. 62.

32 Tamże, s. 56.

33 Tamże, s. 53.

34 Tamże, s. 56.
} 
skania zdrowia”, co może doprowadzić do „fałszywej pociechy” i „niepewnej ufności”, a w konsekwencji do „pewnego potępienia” ${ }^{35}$. Mimo iż w traktacie wspomniane są duchy dobre i złe, wątek walki o duszę umierającego nie jest rozwinięty $^{36}$.

Najrzadziej wspominaną rzeczą ostateczną człowieka w omawianym tekście jest c zyści ec. Gerson mówi o nim tylko jeden raz jako o „męce straszliwego czyśćca". Teolog napomina chorego, aby cierpliwie znosił kary choroby i śmierci, jednocześnie prosząc Boga, aby w swoim miłosierdziu to udręczenie przyjął w zamian za przewidywany c zyści e c. Jest on zatem rozumiany jako pośmiertna kara za „występki”, „wykroczenia” i „grzechy”, która jest o wiele dotkliwsza niż jakakolwiek kara ziemska - „łatwiej bowiem jest wytrzymać karanie tutaj obecnie niż w przyszłości" ${ }^{37}$. W tekście nie ma innych informacji na jego temat.

Ciekawe, że Gerson ani razu nie wspomina o sądzie, jakiemu miałby zostać poddany po śmierci człowiek, ani o sędzim, który miałby go dokonać. Można jedynie doszukiwać się wyrażonej nie wprost idei rozliczenia człowieka po śmierci. Świadczą o tym zwroty pochodzące z języka prawniczego, a $\mathrm{w}$ teologii używane do opisu zagadnienia sprawiedliwości i sądu ${ }^{38}$. Gerson nie zajmuje się także: zmartwychwstaniem, powtórnym przyjściem Chrystusa, końcem świata. Interesuje go jedynie los duszy umierającego człowieka.

\section{Rzeczy ostateczne w dokumencie Międzynarodowej Komisji Teologicznej pt. Aktualne problemy eschatologii (1992)}

Już w pierwszym punkcie dokumentu jego autorzy określają cel, w jakim został napisany: „Będzie [...] czymś odpowiednim przypomnieć z większym naciskiem prawdy wiary katolickiej, które dotyczą przyszłego przeznaczenia. Będziemy starać się wypracować ich syntezę, podkreślając w niej przede wszystkim te aspekty, które bezpośrednio mogą dać odpowiedź na współ-

35 Tamże, s. 62.

${ }^{36}$ Wątek psychomachii, czyli walki duchowej, stanie się głównym tematem i motywem przewodnim innego dzieła z gatunku ars moriedni, a mianowicie Ars moriendi ex variis scripturarum sententiis collecta ..., przypisywanego Mateuszowi z Krakowa; na temat psychomachii zob. M. Włodarski, Ars moriendi, dz. cyt., s. 99-119.

37 J. Gerson, De arte moriendi, dz. cyt., s. 53.

${ }^{38}$ Chodzi przede wszystkim o występujące niemal na każdej stronie traktatu pojęcia: kara, zasługa, wina, darowanie kary, przebaczenie ze strony Jezusa Chrystusa, wykupienie, odkupienie, a także zwroty pokrewne: zapłacić daninę, wykroczenie, występek, przewinienie. Na temat języka prawniczego w eschatologii zob. A. Nitrola, Trattato di escatologia. II. Pensare la venuta del Signore, Cinisello Balsamo (Milano) 2010, s. 545-547. 
czesne niepokoje"39. Nicią przewodnią całego tekstu jest ukazanie rzeczy ostatecznych człowieka w świetle nadziei, jaka płynie z ostatecznego celu stworzenia człowieka, którym jest intymna relacja, komunia z Chrystusem, rozpoczynająca się w życiu doczesnym, trwająca po śmierci i osiągająca swoją pełnię w zmartwychwstaniu podczas paruzji ${ }^{40}$.

Ponieważ zamierzeniem niniejszego artykułu nie jest szczegółowa analiza tekstu MKT, dlatego refleksja zostanie ograniczona jedynie do tych zagadnień, które najpierw zostały poruszone w traktacie De arte moriendi. Chodzi zatem o: śmierć, raj, piekło i czyściec. Umożliwi to ocenę aktualności średniowiecznego tekstu w świetle dokumentu z 1992 roku.

Śmierci poświęcono pkt 6, zatytułowany: „Śmierć chrześcijańska”. Przyznaje się przede wszystkim, że można mówić o ,absurdzie śmierci”, ponieważ istnieje ona „wbrew woli Bożej (por. Mdr 1,13-14; 2,23-24)”. „Śmierć drąży człowieka wewnętrznie”, poprzez co „uderza w osobę”, będącą „,iałem i duszą istotowo zjednoczonymi". W konsekwencji nikt nie ma powodu do wstydu, jeśli odczuwa do niej ,naturalną odrazę”. Nie jest ona bowiem „,czymś upragnionym ani wydarzeniem, które człowiek mógłby spokojnie przyjąć”. $\mathrm{Z}$ tej perspektywy także cierpienie po śmierci osób kochanych jest czymś naturalnym. Dlatego śmierć powinna być przez chrześcijanina przyjmowana „z pewnym uczuciem pokuty"41.

Równocześnie zaznacza się, że śmierć paradoksalnie jest sytuacją szansy, gdyż człowiek może w jej obliczu zachować się tak, jak nie może tego zrobić żadne zwierzę. Dzięki wierze i nadziei w Boga, a także dzięki pragnieniu bycia z Chrystusem, może ją „przekroczyć” i ,przezwyciężyć strach”, który ona w nim wzbudza. Jednym słowem: w jej obliczu „może i musi pokazać się jako człowiek". Zatem śmierć może stać się czymś upragnionym, o czym świadczy wielu świętych, np. św. Paweł. Jest ona bowiem „bramą, która prowadzi do komunii z Chrystusem”, a nie „wyzwolicielką duszy” z ciążącego jej ciała. Mimo iż śmierć rozumiana jako „wyjście z tego ciała” jest pozbawieniem człowieka „pełni egzystencjalnej” (jedności duszy i ciała), zostaje jednak

39 MKT, Aktualne problemy eschatologii, 1.

${ }^{40}$ Ratzinger tak nakreślił cel dokumentu: „Rezultatem owego ponownego, systematycznego przemyślenia ze strony dokumentu Międzynarodowej Komisji Teologicznej jest więc przyjęcie, że we wszystkich swoich aspektach i momentach - w teraźniejszości ziemskiej, w śmierci i w eschatologicznym stanie pośrednim, w eschatologii finalnej, czyli paruzji i powstaniu z martwych - chrześcijańskie nauczanie eschatologiczne będzie musiało zawsze być ogłaszaniem nadziei życia wiecznego, życia rozumianego «w komunii z Chrystusem», «w Kościele», które ze swej strony w eschatologicznym spełnieniu nie pozostawi za sobą historii ludzkiej ani kosmicznego wymiaru człowieka i świata, ale doprowadzi je do definitywnego wypełnienia i udoskonalenia" J. Ratzinger, Introduzione, dz. cyt., s. 16, (tłum. własne).

${ }^{41}$ MKT, Aktualne problemy eschatologii, 6.1. 
przyjęta z powodu nadziei bycia z Chrystusem ${ }^{42}$. Przypomina się, że zgodnie z tradycją wschodnią można wręcz mówić o „dobroci śmierci”, a nawet że „śmierć jest czymś dobrym”, ponieważ tę „,dobroć” nadał jej Chrystus poprzez swoje zmartwychwstanie, czyniąc ją w ten sposób ,warunkiem i drogą" do naszego zmartwychwstania ${ }^{43}$. W konsekwencji dokument mówi o ,pozytywnym aspekcie umierania”, który polega na nowotestamentalnej ,śmierci w Panu” $(\text { Ap } 14,13)^{44}$. Jednak musi być ona „przygotowana przez święte życie”"45.

Za początek śmierci zostają uznane „ból i choroba”, których znoszenie powoduje „udrękę" chorego. Chrześcijanin jest wezwany do „przyjęcia ich w nowy sposób”, „wraz z akceptacją” jako „dopuszczonych przez Boga”. $\mathrm{W}$ ten sposób jesteśmy włączeni w cierpienie i mękę Chrystusa, a w konsekwencji także w chwałę Jego zmartwychwstania ${ }^{46}$.

Dokument mówi także, że śmierć i grzech są połączone „Związkiem pierwotnym". To z powodu grzechu śmierć pojawiła się na świecie (por. Rz 5,12) $i$ to on powoduje, że śmierć jest doświadczeniem nie tylko fizycznym, ale także duchowym, tzn. powoduje oddzielenie człowieka od Boga ${ }^{47}$. Aby śmierć nie prowadziła do oddzielenia wiecznego, czyli do biblijnej „drugiej śmierci” (por. Ap 20,14), człowiekowi został zaoferowany „nowy sposób umierania”, który polega na „uczestnictwu w Misterium Paschalnym Chrystusa”. W sposób praktyczny do tak pojętej śmierci „przygotowują nas” sakramenty: chrztu, Eucharystii i namaszczenia chorych ${ }^{48}$.

Jeśli chodzi o zagadnienie wiecznego szczęścia, to dokument wspomina o nim w wielu miejscach i w różnych kontekstach, ostatecznie umieszczając je w perspektywie zmartwychwstania. Świadczy o tym chociażby następujące stwierdzenie:

Według definicji Benedykta XII, dusze świętych, w pełni oczyszczone „bezpośrednio po śmierci” i, oczywiście, jako oddzielone (,,zmartwychwstaniem własnych ciał”), posiadają pełne szczęście intuicyjnego oglądu Boga. Takie szczęście in se jest doskonałe i nie można wyobrazić sobie niczego, co byłoby specyficznie

42 „W ten sposób życie ziemskie jest skierowane do komunii z Chrystusem po śmierci, którą osiąga się już w stanie duszy oddzielonej, który ontologicznie jest jeszcze niedoskonały i niepełny. Ponieważ komunia z Chrystusem jest wartością wyższą od pełni egzystencjalnej, życie ziemskie nie może być uważane za wartość najwyższą. To usprawiedliwia, doświadczane często przez świętych, mistyczne pragnienie śmierci" - tamże, 6.3 .

43 Tamże, 6.2.

${ }^{44} \mathrm{Na}$ temat „śmierci w Chrystusie” zob. np.: J. Salij, Przekleństwo śmierci i śmierć w Chrystusie. Próba teologii śmierci, w: Śmierć i wiara, dz. cyt., s. 238-239.

${ }^{45}$ MKT, Aktualne problemy eschatologii, 6.3.

46 Tamże, 6.2.

${ }^{47} \mathrm{Na}$ ten temat zob. J. Salij, Przekleństwo śmierci i śmierć w Chrystusie, dz. cyt., s. 235-236.

${ }^{48}$ MKT, Aktualne problemy eschatologii, 6.3; 8.1. 
wyższe. Sama chwalebna przemiana ciała w zmartwychwstaniu jest skutkiem tej wizji w stosunku do ciała ${ }^{49}$.

W dokumencie na określenie tego stanu używa się takich określeń jak: „życie wieczne”, „szczęście nieba”, „wieczne niebieskie szczęście”, „oglądanie Boga «twarzą w twarz»”, „niebo”. Najbardziej skondensowane nauczanie zawarte jest w pkt. 10: „Wielkość zamysłu Bożego i powaga życia ludzkiego”. Międzynarodowa Komisja Teologiczna przypomina, że istotą tego stanu jest życie w przyjaźni, jaką Chrystus ofiarowuje każdemu człowiekowi, który ze swej strony musi przyjąć ją w sposób wolny.

Stan wiecznego szczęścia rozpoczyna się już na Ziemi jako skutek decyzji człowieka, który „otwiera się” na Boga. Dokument przypomina powszechną wolę zbawczą Boga, który „chce, by wszyscy ludzie zostali zbawieni i doszli do poznania prawdy" (1 Tm 2,4).

Dokument z 1992 roku używa określenia raj, które pojawia się u Gersona. Tekst wskazuje na jego podwójne znaczenie: wspólnoty z Chrystusem po śmierci ${ }^{50}$ oraz stanu pierwotnej szczęśliwości człowieka, która została utracona przez grzech pierwszych rodziców ${ }^{51}$.

Zagadnieniu stanu wiecznego nieszczęścia (określanego także jako: „kara wieczna”, „stan ostatecznego potępienia”, „kara należna potępionym”, „wieczne potępienie”, „potępienie" ${ }^{52}$ ) MTK nie poświęca osobnego paragrafu, lecz mówi o nim w związku z czyśćcem i szczęściem nieba. Autorzy przyznają, że są świadomi, iż jest to ta część nauczania Nowego Testamentu, która stanowi wielką trudność dla człowieka, niezależnie od czasu, w jakim przyszło mu żyć. Mimo to przypominają przede wszystkim wiarę Kościoła w ,istnienie stanu ostatecznego potępienia”, który obdarzony wolnością człowiek może wybrać. Jego istotą jest „pozbawienie oglądania Boga i wieczne trwanie tej kary w całym bycie człowieka”. Jest on ,prawdziwą i rzeczywistą możliwością dla każdego”, jednak „Kościół zawsze odrzucał potępienie jakieś konkretnej osoby”. Wieczne potępienie jest konsekwencją życia na ziemi, a dokładniej mówiąc - podejmowanych w nim decyzji, które prowadzą do dobrowolnego, praktycznego zamykania się na Boga. Sposobem na uniknięcie wiecznej kary jest „nawrócenie”, o które dla wszystkich ludzi Kościół modli się nieustannie.

49 Tamże, 5.4.

50 Przywołując rozmowę Jezusa z Dobrym Łotrem na krzyżu (por. Łk 23,43), tłumaczy się: „Raj jest technicznym pojęciem hebrajskim, które odpowiada wyrażeniu Wielki Eden. Przyjmuje się go, nie opisując go później; podstawowa idea podkreśla, że Jezus chce przyjąć dobrego łotra do wspólnoty z sobą bezpośrednio po śmierci" - tamże, 3.4.

51 Tamże, 10.2.

52 Tamże, 8.1, 8.2, 10.3. 
Zagadnieniu c zy ść c a MKT poświęca pkt 8 swojego dokumentu, zatytułowany: „Oczyszczenie duszy przez spotkanie z Chrystusem uwielbionym”. Zostaje tu przedstawione syntetyczne thumaczenie dogmatu o istnieniu stanu oczyszczenia po śmierci nazywanego także czyśćcem ${ }^{53}$, który to stan poprzedza pełnię zjednoczenia z Bogiem i ostateczne zmartwychwstanie. Z tego powodu należy do ,pośredniej fazy eschatologicznej”. Jest on przeznaczony dla tych, którzy są wewnętrznie „,zaciemnieni” przez , «grzechy powszednie», czyli lekkie i pozostałości grzechów, które mogą również pozostać w człowieku usprawiedliwionym po odpuszczeniu winy". Istotą cierpienia w stanie czyśćca jest tęsknota za miłością Chrystusa, „która opóźnia się w posiadaniu osoby umiłowanej, [dlatego człowiek] cierpi, a przez ból oczyszcza się”. Oczyszczenie ma charakter „bierny”. Przypomina się, że można mówić o antycypacji tego stanu podczas życia na ziemi, ponieważ zgodnie z opinią św. Jana od Krzyża istnieje ,pewien paralelizm między oczyszczeniem, które dokonuje się w tak zwanych «nocach» i oczyszczeniem biernym w czyśćcu". Zatem oczyszczenie z przeszkód do pełnego oglądania Boga może dokonać się już ,na ziemi przez pokutę” i sakrament namaszczenia chorych, którego celem jest „oczyszczenie przed śmiercią pozostałości grzechów".

W dokumencie zostaje położony nacisk na rozróżnienie stanu oczyszczenia od stanu ostatecznego potępienia, gdyż „niedbałość” w tym względzie doprowadziła w przeszłości m.in. do utrudnienia dialogu ekumenicznego. Przypomina się więc stanowczo:

Należy absolutnie odrzucić takie rozumienie stanu oczyszczenia przygotowującego na spotkanie z Bogiem, w którym byłby on zbyt podobny do stanu potępienia, jak gdyby różnica między nimi polegała tylko na fakcie, że jeden byłby wieczny, a drugi czasowy; oczyszczenie po śmierci jest „całkowicie inne od kary należnej potępionym”. Stan, którego centrum stanowi miłość, i stan, którego centrum stanowi nienawiść, w żadnym wypadku nie mogą być zestawione ze sobą. Usprawiedliwiony żyje w miłości Chrystusa. Jego miłość staje się bardziej świadoma wraz ze śmiercią ${ }^{54}$.

Podobnie jak traktat Gersona, tak i dokument MKT nie poświęca sądowi wiele miejsca, choć wspomina go kilkakrotnie w kontekście nauki biblijnej i patrystycznej na ten temat. Odniesienie do sądu pojawia się w związku z tematem wiecznego potępienia, ale także reinkarnacji, w celu ukazania powagi życia ludzkiego, które kończy się wraz ze śmiercią, po której następuje sąd

${ }^{53}$ Tamże, 8.1, 8.2.

54 Tamże, 8.2. 
potwierdzający na wieczność wybór człowieka, bez możliwości rozpoczęcia nowego życia na ziemi w innym ciele ${ }^{55}$.

\section{Eschatologia De arte moriendi w świetle eschatologii dokumentu Aktualne problemy eschatologii}

Po przedstawieniu eschatologii zawartej w De arte moriendi Gersona i w dokumencie MKT pt. Aktualne problemy eschatologii należy przystąpić do porównania opisu poszczególnych rzeczy ostatecznych w obu analizowanych tekstach, poprzez wskazanie zbieżności i różnic między oboma stanowiskami.

Jeśli chodzi o śmierć, to obydwa teksty traktują ją jako wydarzenie, do którego można i należy się przygotować. U Gersona świadczy o tym przede wszystkim motyw napisania dzieła, natomiast w dokumencie MKT wprost mówi się o przygotowaniu ,śmierci w Panu”. Jednak w traktacie średniowiecznym przygotowanie zawęża się do postaw i zachowań chorego $\mathrm{w}$ niebezpieczeństwie śmierci, podczas gdy w tekście z 1992 roku przygotowanie przedstawione jest w szerszej perspektywie, gdyż rozciąga się na całe życie ${ }^{56}$. Obydwa teksty zaliczają do przygotowania przyjęcie sakramentów: chrztu (MKT), Eucharystii i namaszczenia chorych (Gerson, MKT), a także spowiedzi (Gerson).

W obu przypadkach potwierdzona zostaje powszechność śmierci, mimo że De arte moriendi czyni to dosadniej, przypominając o „daninie śmierci”, która dotyczy „królów, książąt, biednych i bogatych”. W dokumencie MKT świadczy o tym kontekst wypowiedzi, a nie konkretne sformułowania.

Także powiązanie śmierci z chorobą jest cechą wspólną omawianych tekstów. W obu przypadkach niemoc cielesna uznawana jest za możliwą przyczynę (Gerson) lub początek (MKT) śmierci. Również cierpienie, ból i strach towarzyszą umieraniu i są powodem udręki człowieka (Gerson, MKT).

Podobnie zostają przyporządkowane do siebie śmierć i grzech. Gerson bez zbędnych wywodów traktuje śmierć, jak wcześniej chorobę, jako karę za grzechy. Dokument MKT w istocie rzeczy mówi o tym samym, używając jednak sformułowań teologicznych i odniesień biblijnych.

Obydwa dokumenty przypominają o wolności człowieka, z której wynika konieczność decydowania o losie po śmierci. Jednak Gerson za szczególny moment podejmowania decyzji uważa chwilę śmierci, natomiast MKT decy-

55 Tamże, 9.3, 10.3.

56 Silne koncentrowanie się na momencie śmierci i procesie umierania, kosztem nauki o pobożnym i dobrym życiu, jest uważane za jedną z cech średniowiecznej ars moriendi, zob., H. Rolfes, Ars moriendi, dz. cyt., s. 25. 
dowanie omawia w szerszym kontekście, tzn. zbawienia i potępienia wiecznego. W konsekwencji, w obu przypadkach mowa jest o konieczności dobrowolnego przyjęcia, akceptacji i cierpliwego zanoszenia śmierci. Gerson uważa, że taka postawa prowadzi do darowania umierającemu grzechów, win i kar, a MKT dodaje, że jest to możliwe dzięki ofiarowaniu człowiekowi ,nowego sposobu umierania", którego istotą jest uczestnictwo w męce Chrystusa. Gerson wzywa jednocześnie do przebaczenia i prośby o przebaczenie oraz do zadośćuczynienia, a MKT wskazuje na pokutny charakter akceptowania własnej śmierci.

Obydwa teksty uważają śmierć za sytuację szansy (ostatniej, jak podkreśla Gerson). Średniowieczny tekst z założenia ma służyć „dobremu umieraniu”, czyli zgodnemu z wymienionymi w nim zasadami i przepisami w celu osiągnięcia raju. Dokument z 1992 roku dobroć upatruje w tym, że śmierć jest przemieniona przez zmartwychwstałego Chrystusa, który uczynił z niej drogę do naszego zmartwychwstania. Dlatego człowiek jest zdolny do zachowania się w jej obliczu całkowicie inaczej od zwierząt i dzięki relacji do Boga traktować ją jako „bramę” do życia z Chrystusem (MTK). W ten sposób w obu dokumentach zostaje ujawniona pozytywna strona śmierci.

Oprócz cech śmierci omawianych w obu tekstach istnieją także te, które zostały wskazane tylko w jednym z nich. Tylko Gerson przypomina, że śmierć może być „,nagła”, przez co „zaskakuje” człowieka. Jako taka nie jest śmiercią pożądaną. Także tylko teolog z Paryża ukazuje śmierć jako moment szczególnej modlitwy błagalnej, zanoszonej tak przez chorego, jak i przez towarzyszące mu osoby. Tych tematów nie podejmuje MKT, choć wiąże śmierć z modlitwą, jednak rozumianą jako wstawiennictwo za dusze doznające oczyszczenia po śmierci ${ }^{57}$. Z drugiej strony tylko Komisja przypomina, że śmierć może stać się wydarzeniem upragnionym, jak miało to miejsce w przypadku wielu świętych, a ponadto, że śmierć to rozdzielnie duszy i ciała ${ }^{58}$.

Jeśli chodzi o stan wiecznego szczęścia, to omawiane teksty używają na jego określenie odmiennych terminów za wyjątkiem jednego, który występuje w obu: raj. Międzynarodowa Komisja Teologiczna poszerza jego zakres znaczeniowy, odnosząc go nie tylko do stanu po śmierci, lecz także do sytuacji pierwotnego szczęścia pierwszych rodziców. Tak Gerson, jak i MKT jako istotę raju po śmierci wskazują wspólnotę z Chrystusem. Podkreślają także, że szczęście to nie jest zasługą człowieka, lecz darem ofiarowanym, którego należy pragnąć, o który trzeba prosić (Gerson) i który należy przyjąć w wolności (MKT). W obu tekstach wieczne szczęście jest uważane za cel życia człowieka. Międzynarodowa Komisja Teologiczna traktuje to zagadnienie w kontekś-

${ }^{57}$ MKT, Aktualne problemy eschatologii, 8.1, 11.3.

58 Tamże, 6.1. 
cie przyszłego zmartwychwstania, do czego nie odnosi się w żaden sposób Gerson $^{59}$.

Oba teksty uczą o istnieniu stanu wiecznego nieszczęścia, zgodnie używając na jego określenie różnych wariantów tradycyjnych sformułowań, takich jak: „kara wieczna”, „piekło”, „potępienie”. W obu przypadkach zaznacza się, że potępienie nie jest zamierzonym przez Boga zwieńczeniem egzystencji, a jedynie konsekwencją życia i decyzji człowieka. Międzynarodowa Komisja Teologiczna dodaje, że nie można określić, kto z ludzi potępił się de facto. Ani średniowieczny traktat, ani dokument z 1992 roku nie podejmują zagadnienia wpływu złych duchów na los człowieka, choć Gerson kilkakrotne o nich wspomina.

Jeśli chodzi natomiast o stan oczyszczenia duszy po śmierci zwany czyśćcem, widać znaczącą rozbieżność w sposobie przedstawienia go w omawianych tekstach. Gerson mówi o nim bardzo krótko, przestrzegając przed nim i wzywając do podejmowania dobrowolnego cierpienia jeszcze na Ziemi, aby uniknąć bólu w czyśćcu po śmierci. Natomiast MKT poświęca temu stanowi cały pkt 8 , w którym dość szczegółowo zostaje wyłożona teologia czyśćca. Tym, co łączy oba stanowiska, jest wskazanie na możliwość uprzedniego doświadczenia i odpokutowania cierpień, które w czyśćcu będą konsekwencjami popełnionych na ziemi grzechów. Jednak na uwagę zasługuje przede wszystkim znacząca różnica w rozumieniu stanu oczyszczenia po śmierci przez Gersona i MKT. Średniowieczny teolog opisuje bowiem czyściec w taki sposób, że trudno oprzeć się wrażeniu, iż skłania się bardziej do łączenia go ze stanem wiecznej kary dla potępionych niż do pośredniej fazy oczyszczenia osób już zbawionych. Gersonowskie pojęcie „męki straszliwego czyśćca” raczej zatrważa, niż umacnia nadzieję na zbawienie. Nie wiadomo bowiem, czy Gerson uważa, czy też nie, kary czyśćca za „całkowicie inne od kary należnej potępionym”, jak chce MKT. Paryski teolog nie tłumaczy, jak rozumieć dość szokujący opis pośmiertnego oczyszczenia. Trudno zatem oprzeć się wrażeniu, że stwierdzenie MKT o „niedbałości” w odróżnianiu stanu oczyszczenia od stanu ostatecznego potępienia może być odniesione także do nauki zawartej w De arte moriendi.

Kontekst społeczny i teologiczny powstania obu tekstów wpłynął tak na ich formę, jak i treść. Jeśli chodzi o formę, wydaje się, że współczesny czy-

59 Wypływa to zapewne z przekonania średniowiecznych autorów ars moriendi o tym, że „die Seele übertreffe den Wert des Körpers, so wird festgestellt, weil sie für die Ewigkeit geschaffen sei" - H. Rolfes, Ars moriendi, dz. cyt., s. 32; zob. także: M. Włodarski, Trzy traktaty, dz. cyt., s. 72. 
telnik traktatu Gersona może odnieść wrażenie, iż autorowi bardziej zależy na ukazaniu niebezpieczeństwa związanego z możliwością cierpienia duszy w czyśćcu i w piekle niż na przedstawieniu piękna i szczęścia, jakie czekają na nią w raju. „Danina śmierci”, ,uniknięcie straszliwych kar piekielnych”, „kara miecza”, „srogość obecnego bólu”, „męka straszliwego czyśćca”, „wieczna kara”, „uratować ginącego od przepaści piekielnej”, „chwytanie i pożeranie duszy przez złe duchy i psy piekielne" - te zwroty dla wielu ludzi XXI wieku mogą być nie do przyjęcia i mogą nie pomagać w odnowieniu wiary w Boga i w poprawie życia, co było celem ich użycia sześć wieków temu. Dużo bliższe naszej religijnej wrażliwości wydaje się pouczenie Gersona o tym, że ,jeśli chory utracił zdolność mówienia, zachowuje jednak pełne i zdrowe rozumienie, niech odpowiada jakimś znakiem zewnętrznym lub tylko zgodą serca na zadawane mu pytania lub odmawiane przy nim modlitwy, to bowiem wystarczy do zbawienia". Słowa te ukazują bowiem, że miłość Boga do człowieka jest tak wielka, że jest wrażliwa na każdy, nawet najmniejszy przejaw skruchy $\mathrm{z}$ jego strony.

Co się zaś tyczy treści tekstu średniowiecznego teologa, należy zauważyć, że mówiąc o rzeczach ostatecznych człowieka, stawia akcenty w odmienny sposób od MKT. Odmienny, nie oznacza bynajmniej przeciwstawny, lecz komplementarny. Międzynarodowa Komisja Teologiczna nakreśliła dużo szerszą pespektywę eschatologiczną niż Gerson, niejako zawierając w swoim dokumencie zagadnienia podjęte w De arte moriendi. Jest to zrozumiałe, gdyż średniowieczny autor chciał stworzyć skuteczne i zwięzłe narzędzie duszpasterskie, a nie spisać akademicki wykład. Nie powinno zatem dziwić współczesnego czytelnika, że Gerson nie omawia podjętych przez Komisję problemów reinkarnacji ${ }^{60} \mathrm{i}$ wywoływania duchó ${ }^{61}$. Z tego samego powodu nie znajdziemy u niego specyficznych określeń teologicznych przynależących do eschatologii akademickiej, jak: ,paruzja”, ,stan pośredni”, „dusza oddzielona”, „Ganztod”. Może natomiast zastanawiać fakt, że nie mówi wprost o sądzie po śmierci i w ogóle nie wspomina o zmartwychwstaniu.

Próbując odpowiedzieć na pytanie postawione w tytule artykułu, a mianowicie, czy dzieło Gersona powinniśmy włożyć do lamusa jako średniowieczny przeżytek, czy jednak można je ocalić i uznać za dar dla nas współczesnych, wydaje się, że na podstawie dokonanej krótkiej analizy traktatu należy sformułować trzy następujące wnioski: (1) Godny podziwu jest zapał duszpasterski paryskiego profesora i jego troska o szczęście wieczne ludzi ${ }^{62}$. Jego konkretnym owocem stało się stworzenie „podręcznika” dla umierających,

${ }^{60}$ MKT, Aktualne problemy eschatologii, 9.

61 Tamże, 7.2

62 To główny cel, charakteryzujący średniowieczne dzieła o sztuce umierania, zob. H. Rolfes, Ars moriendi, dz. cyt., s. 35 . 
a jednocześnie dla osób im towarzyszących, który może być traktowany jako zwięzły katechizm podstawowych prawd wiary. Gerson jest godnym naśladowania wzorem teologa, który swoją wiarą i wiedzą o ,przyszłym świecie” może posłużyć ludziom umierającym. (2) Oczywiste wydaje się, że język, styl, użyte obrazy nie są do automatycznego przejęcia i powielenia we współczesnej literaturze ars moriendi czy przepowiadaniu o rzeczach ostatecznych. Należałoby dostosować je do obecnej mentalności. Od Gersona warto jednak przejąć zwięzły i konkretny sposób nazywania „rzeczy po imieniu”, bez zbędnych, teoretycznych wywodów. (3) Jeśli chodzi w końcu o zgodność eschatologii przekazanej w De arte moriendi ze współczesną nauką o rzeczach ostatecznych, należy ją potwierdzić, dodając jednak, że dwie rzeczy powinny być skorygowane. Po pierwsze, należałoby jaśniej przedstawić naukę o czyśćcu jako pośredniej fazy eschatologicznej należącej już do stanu zbawienia, wzbogacając ją o zwięzłą, przemyślaną i jasno przedstawioną teologię i praktykę odpustów ${ }^{63}$. Po drugie, trzeba by uwzględnić omówienie sądu, tak szczegółowego, jak i powszechnego, zmartwychwstania, a także - idąc po linii dokumentu MKT z 1992 roku - podjąć w zreflektowany sposób zagadnienie reinkarnacji i poprawnie rozumianej wspólnoty z duszami zmarłych ${ }^{64}$.

Podsumowując jednym zdaniem: traktat J. Gersona pt. De arte moriendi nie jest przeżytkiem rodem z wieków średnich, lecz jako wyraz żywej wiary w obiecane przez Chrystusa życie wieczne i duszpasterskiej troski jest darem dla współczesnych w tym sensie, że ma moc inspirowania do ciągłego namysłu nad rzeczami ostatecznymi i do głoszenia ponadczasowej wartości przygotowania się do śmierci, która jest bramą do pełni życia, a nie ślepym zaułkiem.

${ }^{63}$ Na temat historii odpustów zob. np. G.L. Müller, Dogmatyka katolicka, Kraków 2015, s. 738-745; a na temat ich teologii zob. np. R. Pisula, Odpusty w Misterium Kościoła. Źródla, natura, praktyka, Poznań 2001. Warto byłoby także zastanowić się, czy zamiast mówić o karach jakie musi cierpieć dusza w czyśćcu, nie byłoby lepiej używać pojęcia konsekwencji czy skutków grzechów, gdyż „odciążyłoby to” przytłaczający obraz Boga - karzącego Sędziego i zwróciło większą uwagę na odpowiedzialność człowieka za własne czyny, a przez to za swój los po śmierci.

${ }^{64} \mathrm{Na}$ temat potrzeby podjęcia tematu rzeczy ostatecznych w perspektywie wspólnotowej, a nie tylko indywidualnej zob. H. Rolfes, Ars moriendi, dz. cyt., s. 38-40. 


\section{J. GERSON'S DE ARTE MORIENDI - A MEDIEVAL ANACHRONISM OR A GIFT FOR CONTEMPORARY PEOPLE? \\ AN ATTEMPT OF ANALYSIS IN THE LIGHT OF DOCUMENT SOME CURRENT QUESTIONS IN ESCHATOLOGY RELEASED BY INTERNATIONAL THEOLOGICAL COMMISSION (1992)}

\section{Summary}

Death is a part of human life - a part which cannot be deleted. Both earlier and nowadays it pushes people to ask about its reason, consequences, nature and how to get ready for it. The response for the ultimate question were books about the art of dying, which first of all were written in the Middle Ages.

People are dying also today, so there is a need to work out a "new art of dying", which is compatible with the mentality of a contemporary human being. The first step is to analyse if and how medieval texts can help or explain it. An analysis in the light of contemporary eschatology of one of such texts: De artre moriendi written by $\mathrm{J}$. Gerson is the point of the following article.

The first chapter is about the final things in human life such as death, paradise, purgatory and hell, which are described by Gerson. In the second chapter there is presented the teaching of the International Theological Commission concerning those issues enclosed in the document Some current questions in Eschatology (1992). The third chapter is an attempt to compare the eschatology of both texts.

The study allows to draw a conclusion that the medieval treatise of Gerson is not an anachronism, but might be a precious inspiration for contemporary theologians. Eschatology included in that treatise is faithful to contemporary eschatology, so it is possible, after doing some revisions and additions, to build ars moriendi for contemporary human based on it.

Słowa kluczowe: ars moriendi; śmierć; raj; czyściec; piekło; współczesność

Keywords: ars moriendi; death; paradise; purgatory; hell; the present time

\section{BIBLIOGRAFIA}

Ars moriendi ars vivendi ars educandi, red. Z. Rudnicki, Poznań 2012.

Bartoszewski K., Zbiciak J., Ars moriendi, w: Encyklopedia katolicka, red. F. Gryglewicz i in., Lublin 1973, t. 1, kol. 950-951.

Bartoszewski L., Zanim nadejdzie śmierć... czyli ars bene moriendi, Gdańsk 2015.

Baumgartner K. i in., Ars moriendi, w: Leksikon für Theologie und Kirche, red. W. Kasper i in., Freiburg-Basel-Rom-Wien $1993^{3}$, t. 1, kol. 1035-1038.

Bellarmin R., De arte bene moriendi, tekst angielski zob: https://archive.org/details/theartofdyingwel00belluoft [dostęp: 03.04.2017].

Berthier J., Metoda asystowania umierającym (1891), thum. W. Biedrzycki, Górka Klasztorna 2015. 
Biedrzycki W., Przy łożu śmierci. „,Metoda towarzyszenia umierajacym” ks. Jana B. Berthiera, $\mathrm{w}$ : Śmierć $i$ wiara $w$ życie pośmiertne $w$ świetle nauk przyrodniczych $i$ humanistycznych, red. M. Machinek, Biblioteka Wydziału Teologii 17, Olsztyn 2003, s. 257-267.

Capranica D., Speculum artis bene moriendi, w: M. Włodarski, Trzy traktaty o sztuce umierania, Kraków 2015, s. 121-212.

Gerson J., De arte moriendi, przekład i opracowanie M. Włodarski, w: M. Włodarski, Trzy traktaty o sztuce umierania, Kraków 2015, s. 43-62.

Hausberger K., Johannes Chalier Gerson, w: Leksikon für Theologie und Kirche, red. W. Kasper i in., Freiburg-Basel-Rom-Wien 199633, t. 5, kol. 909-910.

Liguori A., Przygotowanie do śmierci, tłum. J. Serafin, Kraków 2016.

Machinek M., Czy umieranie jest sztuką? O chrześcijańskiej „,ars moriendi”, w: Śmierć i wiara $w$ życie pośmiertne $w$ świetle nauk przyrodniczych i humanistycznych, red. M. Machinek, Biblioteka Wydziału Teologii 17, Olsztyn 2003, s. 241-255.

Machinek M., Śmierć w dyspozycji człowieka. Wybrane problemy etyczne u kresu ludzkiego życia, Bibliotek Wydziału Teologii 22, Olsztyn 2004².

Machinek M., Towarzyszyć w ostatniej drodze. „Metoda asystowania umierajacym” ks. Jana Berthiera a wspótczesna troska o umierajacych, w: Cor unum et anima una, red. A.J. Sobczyk, Pelplin 2009, s. 79-94.

Manser J., , Wer mich zum Freunde hat, dem kann's nicht fehlen”. Versuch einer spirituellen Theologie zur Ars moriendi heute, w: Erwägungen zur Kunst des Sterbens, red. H. Wagner, T. Kruse, Quaestiones Disputatae 118, Freiburg-Basel-Wien 1989, s. 69-98.

Mateusz z Krakowa, Ars moriendi ex variis scripturarum sententiis collecta, w: M. Włodarski, Trzy traktaty o sztuce umierania, Kraków 2015, s. 63-120.

Międzynarodowa Komisja Teologiczna, Aktualne problemy eschatologii (1992), http://www.vatican.va/roman_curia/congregations/cfaith/cti_documents/rc_cti_1990_problemi-attuali-escatologia_pl.html [dostęp: 03.04.2017].

Misiurek J., ,Ars moriendi” - sztuka umierania, w: Cierpienie i śmierć, red. A. Nowak, Homo Meditans 13, Lublin 1992, s. 231-244.

Müller G.L., Dogmatyka katolicka, tłum. W. Szymona, Kraków 2015.

Nitrola A., Trattato di escatologia. II. Pensare la venuta del Signore, Cinisello Balsamo (Milano) 2010.

Pieńkowska-Wyżyńska B., Sztuka dobrego umierania, Kraków 2015.

Pisula R., Odpusty w Misterium Kościoła. Źródła, natura, praktyka, Poznań 2001.

Ratzinger J., Introduzione, w: Congregazione per la Dottrina della Fede, Temi attuali di escatologia, Vaticano 2000, s. 9-17.

Rolfes H., Ars moriendi. Eine Sterbekunst aus der Sorge um das ewige Heil, w: Ars moriendi. Erwägungen zur Kunst des Sterbens, red. H. Wagner, T. Kruse, Quaestiones Disputatae 118, Freiburg-Basel-Wien, 1989, s. 15-44.

Salij J., Przekleństwo śmierci i śmierć w Chrystusie. Próba teologii śmierci, w: Śmierć i wiara wżycie pośmiertne w świetle nauk przyrodniczych i humanistycznych, red. M. Machinek, Biblioteka Wydziału Teologii 17, Olsztyn 2003, s. 231-240.

Wagner H., „Ars moriendi” und Religionspädagogik, w: Ars moriendi. Erwägungen zur Kunst des Sterbens, red. H. Wagner, T. Kruse, Quaestiones Disputatae 118, Freiburg-Basel-Wien 1989, s. $156-165$.

Włodarski M., Ars moriendi w literaturze polskiej XV i XVI w., Kraków 1987.

Włodarski M., Trzy traktaty o sztuce umierania, Kraków 2015.

Wielgus S., Gerson, w: Encyklopedia katolicka, red. Bienkowski L. i. in., Lublin 1989, t. 5, kol. 1018-1020.

Wohlmuth J., Mistro della trasformazione. Tentativo di una escatologia tridimensionale, in dialogo con il pensiero ebraico e la filosofia contemporanea, Biblioteca di Teologia Contemporanea 164, Brescia 2013.

Zwoliński A., Ars moriendi. Sztuka towarzyszenia umierającym, Poznań 2016. 
Bogdan KULIK MSF - ks. dr, kapłan ze Zgromadzenia Misjonarzy Świętej Rodziny. Ukończył Papieski Uniwersytet Gregoriański w Rzymie. Wykładowca teologii dogmatycznej w Wyższym Seminarium Duchownym Misjonarzy Świętej Rodziny w Kazimierzu Biskupim. Rekolekcjonista i krajowy duszpasterz Apostolstwa Dobrej Śmierci - stowarzyszenia, którego celem jest przygotowywanie do chrześcijańskiej śmierci poprzez budzenie i umacnianie wiary w życie wieczne. Redaktor naczelny biuletynu tegoż Apostolstwa - kwartalnika „Nadzieja i Życie" (www.apostolstwo.pl). 